Neth. J. Pl. Path. 96 (1990) 17-28

\title{
Simulation of yield reduction by leaf rust in winter wheat, applied to the analysis of genetic variation in partial resistance
}

\author{
H.J.W. VAN ROERMUND' and C.J.T. SPITTERS ${ }^{2,3}$ \\ 1 Department of Theoretical Production Ecology, Wageningen Agricultural University, P.O. \\ Box 430, $6700 \mathrm{AK}$ Wageningen, the Netherlands \\ 2 Foundation for Agricultural Plant Breeding (SVP), P.O. Box 117, 6700 AC Wageningen, the \\ Netherlands \\ ${ }^{3}$ Present address: Centre for Agrobiological Research (CABO), P.O. Box 14, 6700 AA Wagen- \\ ingen, the Netherlands
}

Accepted 20 September 1989

\begin{abstract}
Differences in yield reduction among seven winter wheat genotypes due to leaf rust, as observed in a field experiment, were analysed using a simulation model. In this model, the effects of the discase on crop growth and yield were described on the basis of light interception, photosynthesis, respiration and assimilate partitioning. The model properly described the observed yield difference between the genotypes, both in the absence and in the presence of leaf rust. According to the model, $66 \%$ of total yield reduction was due to an accelerated decrease in green leaf area and $18 \%$ was due to light capture by dead leaf tissue at the top of the canopy. Genetic variation in yield reduction was, therefore, mainly explained by variation in leaf senescence. Leaf rust did not affect the photosynthetic rate of the remaining green leaf area. Opportunities of selection for individual damage components were assessed from their simulated effect on grain yield, together with their estimated genetic and environmental variance.
\end{abstract}

Additional keywords: Puccinia rcondita, Triticum aestivum, model, photosynthesis, competition for light.

\section{Introduction}

Infection with leaf rust (Puccinia recondita Rob. ex. Desm. f.sp. tritici) reduces grain yield of winter wheat (Triticum aestivum $\mathrm{L}$.). Wheat genotypes have been found which totally prevent fungus multiplication, i.e. spore production is zero (complete resistance), or which reduce its multiplication rate (partial or non-hypersensitive resistance; Kuhn et al., 1978; Parlevliet, 1979). Wheat genotypes might differ in their ability to endure the effects of parasitic infection, which, if it occurred at an equal level in other genotypes would cause greater impairment of growth or yield (tolerance; Clarke, 1986).

In an earlier paper, differences in yield reduction between winter wheat genotypes due to leaf rust were attributed to differences in disease progress and to differences in acceleration of plant senescence (Spitters et al., 1990). The variation in yield reduction can be analysed further by dividing epidemiology, crop growth and their interaction into various subprocesses. In breeding research, such a strategy is already used 
to some extent with respect tot partitioning of resistance into different components (Shaner and Hess, 1978; Parlevliet, 1979; Van Oijen, 1989). The effect of disease intensity on crop growth and yield has, however, received little attention in that respect, probably because of the complexity of the interaction between epidemiology and crop growth.

Computer simulation models can be useful in integrating the underlying processes of crop growth over time and over levels of biological organization. In the present paper, an explanatory simulation model is presented, in which the effect of leaf rust epidemics on growth of winter wheat is described in terms of crop physiological processes. The model is used to explain the observed variation in yield reduction of seven winter wheat genotypes by analysing the effects of leaf rust on the physiological components of crop growth. A sensitivity analysis of the components is performed and the genotypic and environmental variances of the components are estimated to assess perspectives of breeding for the individual components.

\section{Materials and methods}

A field experiment was carried out at Lelystad (East Flevopolder, the Netherlands) in $1985 / 1986$ to study the epidemiology of leaf rust and its effect on grain yield for seven winter wheat genotypes and one leaf rust isolate (Spitters et al., 1990). The seven winter wheat genotypes were 'Cappelle Desprez', 'Okapi', 'Heine's II', 'Halle stam 6728-45', 'Cerco', 'SVP-73035-45-1' and 'SVP-73043-38-1'; the leaf rust isolate was the 'Limburgs' isolate with intermediate virulence.

Pustule density on the three upper leaves and green area of leaves and ears per culm were scored at weekly intervals. Maximum flag leaf photosynthesis at light saturation was measured in the field at various leaf rust severities for 'Cappelle Desprez', 'Okapi' and 'SVP-73043-38-1'. At harvest, total grain weight, 1000-kernel weight and culm density were determined.

\section{The simulation model}

Crop growth. To simulate the growth and development of winter wheat, a modified version of the wheat model described by Spitters et al. (1989) was used. The model simulates dry matter production during the season under favourable soil nitrogen and moisture conditions, depending upon environmental conditions of radiation and temperature. Dry matter production is obtained by integrating the crop growth rate over time. The daily rate of crop growth $(\mathrm{d} W / \mathrm{d} t)$ is calculated from the gross photosynthetic rate of the canopy $\left(A_{\mathrm{g}}\right)$, maintenance respiration $\left(R_{\mathrm{m}}\right)$, and efficiency of conversion of carbohydrates into structural plant material $\left(C_{\mathrm{f}}\right)$ :

$$
\mathrm{d} W / \mathrm{d} t=C_{\mathrm{l}}\left(A_{\mathrm{g}}-R_{\mathrm{m}}\right)
$$

The daily rate of canopy photosynthesis is obtained by integrating instantaneous rates of leaf photosynthesis over the leaf area index of the canopy and over the day. Leaf photosynthesis is computed from the incident amount of photosynthetically active radiation (PAR) above the canopy, the distribution of PAR over the leaves and the photosynthesis-light response of individual leaves. This response is characterized by the maximum net photosynthesis at light saturation $\left(A_{\mathrm{m}}\right)$ and the efficiency at low light in- 
tensities $(\epsilon)$. Maintenance respiration depends on the composition and amount of biomass and is affected by temperature. The conversion efficiency depends on the chemical composition of the dry matter formed.

The formed dry matter is allocated to the various growing plant organs: leaves, stems, and roots. A pool of carbohydrate reserves is distinguished to take account of the sourcesink relations in grain growth. The source consists of the current net photosynthesis and the available carbohydrate reserves. Actual grain growth is limited either by available carbohydrates (source limited) or by potential grain growth (sink limited). Potential grain growth is calculated from the potential growth rate of an individual kernel, multiplied by the total number of kernels. Potential individual kernel growth depends on temperature and on crop development stage. In the model version used here, total kernel number is calculated from culm density and the density dependent number of kernels per ear, according to Darwinkel (1978). The model was initialized with crop development stage and dry weights of leaves, stems and roots at the beginning of April. When describing the effects of leaf rust epidemics becoming evident shortly before anthesis, simulation of crop growth during winter and early spring is not necessary.

Disease progress. The crop growth model has been extended by incorporating the effects of leaf rust on plant physiological parameters. The amount of disease is quantified by the pustule density, which is described by a logistic function of time. The initial pustule density $\left(N_{0}\right.$ in pustule $\mathrm{cm}{ }^{2}$ leaf $)$, the maximum pustule density $\left(N_{\mathrm{m}}\right.$ in pustule $\mathrm{cm}^{-2}$ leaf $)$ and the apparent infection rate $\left(r\right.$ in $\left.\mathrm{d}^{-1}\right)$ were estimated from the experimental data. The epidemic started 10 days after inoculation (Spitters et al., 1990). It is assumed that pustule density decreases after the last leaf rust observation in the field on 18 July at a rate equal to the relative leaf death rate. Accumulated amount of disease over the whole season is calculated by integrating pustule density over time (pustules $\mathrm{cm}^{2}$ leaf day), i.e. the 'area under disease-progress-curve' (VanderPlank, 1963; James, 1974).

Effect of leaf rust on crop growth. Leaf rust may affect the rate of crop growth by a) reduction in leaf photosynthesis $\left(A_{m}, \epsilon\right)$, b) increase in leaf dark respiration, c) uptake of assimilates by the fungus, d) leaf coverage by pustules, e) premature and accelerated leaf senescence and $\mathrm{f}$ ) premature and accelerated ear senescence.

ad a) A reduction in $A_{\mathrm{m}}$ was observed in the field. This reduction was fully explained by the reduction in green leaf area and no change of $A_{\mathrm{m}}$ per unit of green leaf area was observed (Spitters et al., 1990). Despite a lack of quantitative data, it was assumed that the same holds for $\epsilon$. The reduction in green leaf area is quantified under e).

ad b) Leaf dark respiration may increase after fungus infection due to higher metabolic activity of the plant and to fungus respiration. Quantitative data on the increase in metabolic activity of wheat after leaf rust infection are not available. It was assumed that effects of infection on leaf dark respiration can be neglected. Fungus respiration will be quantified under $\mathrm{c}$ ).

ad c) The rate of assimilate uptake by the fungus is derived from its spore production rate. The uptake rate of carbohydrates required to produce spores $\left(U_{\mathrm{c}}, \mathrm{kg} \mathrm{CH}_{2} \mathrm{O}\right.$ ha ${ }^{-1}$ $\left.\mathrm{d}^{\prime}\right)$ equals the total daily spore production rate, $\left(R_{\mathrm{t}}, \mathrm{kg}\right.$ spore dry mass ha $\left.{ }^{-1} \mathrm{~d}^{-1}\right)$, multiplied by the assimilate requirement to produce $1 \mathrm{~kg}$ spores $\left(c_{\mathrm{s}}, \mathrm{kg} \mathrm{CH}_{2} \mathrm{O} \mathrm{kg}^{-1}\right.$ spore dry matter):

Neth. J. Pl. Path. 96 (1990) 


$$
U_{\mathrm{c}}=R_{\mathrm{t}} \cdot c_{\mathrm{s}}
$$

The assimilate requirement for spores depends on the chemical composition of the spore biomass and is calculated according to Shaw (1964) and Penning de Vries et al. (1983) as $1.67 \mathrm{~kg} \mathrm{CH}_{2} \mathrm{O} \mathrm{kg}{ }^{1}$ spore DM. This is slightly lower than that of cultured bacteria; an efficiency of $60 \%$ was measured (expressed in carbon), which equals $1.87 \mathrm{~kg} \mathrm{CH}_{2} \mathrm{O}$ $\mathrm{kg}^{-1} \mathrm{DM}$ at a carbon fraction of 0.45 . For fungi also, the efficiency is thought to be around $60 \%$ (Calow, 1977). Total daily spore production rate $\left(R_{1}\right)$ is computed from pustule density $\left(N_{1}\right.$ in pustule $\mathrm{cm}^{2}$ leaf) and daily spore production rate per pustule $\left(R_{\mathrm{p}}\right.$ in $\mathrm{kg}$ spore DM pustule $\left.{ }^{\prime} \mathrm{d}{ }^{\prime}\right)$ :

$$
R_{\mathrm{t}}=\left(N_{1} \cdot \mathrm{LAI} \cdot 10^{\mathrm{R}}\right) \cdot R_{\mathrm{i}}
$$

were LAI is the leaf area index ( $\mathrm{cm}^{2}$ leal $\mathrm{cm}^{2}$ ground). $R_{p}$ is assumed to decrease exponentially with pustule density (Mehta and Zadoks, 1970):

$$
R_{\mathrm{p}}=10^{9} \cdot \exp \left(0.384-0.000977 . N_{\mathrm{t}}\right)
$$

As a result, the pool of carbohydrate reserves in the plant decreases with $U_{c}$. As quantitative data on mycelium biomass of a fungus in the host plant are lacking, the effect of growth and maintenance of mycelium are not taken into account. A sensitivity analysis is performed to evaluate this yield reduction component under the assumption of a spore/total fungus biomass ratio of 0.5 .

ad $\mathrm{d}, \mathrm{e}, \mathrm{f})$ Leaf coverage with pustules and premature and accelerated leaf and ear senescence (yellowing) reduce the rate of canopy photosynthesis by (1) a reduction of the photosynthetic surface of leaves and ears and by (2) light interception by photosynthetically inactive tissues.

Leaf area covered by pustules is calculated by multiplying the pustule density $\left(N_{1}\right)$ by the pustule size. Senesced leaf and ear areas in the absence of leaf rust were linearly related to the temperature sum $\left({ }^{\circ} \mathrm{C}\right.$ d; daily average temperatures were accumulated above a base of $0{ }^{\circ} \mathrm{C}$ ), as inferred from the field observations. The regression slope reflects the death rate (in $\mathrm{m}^{2}$ area $\mathrm{m}^{2}$ ground ${ }^{\circ} \mathrm{C}^{-1} \mathrm{~d}^{-1}$ ). The experimental data suggested that in the presence of leaf rust, the senesced area was related exponentially rather than linearly to the pustule temperature sum in pustule $\mathrm{cm}^{-2}$ leaf ${ }^{\circ} \mathrm{C} \mathrm{d}$. The regression slope of the natural logarithm of green area on the pustule temperature sum then reflects the relative death rate (in pustule ${ }^{-1} \mathrm{~cm}^{2}$ leaf ${ }^{\circ} \mathrm{C}^{-1} \mathrm{~d}^{-1}$ ). Senescence proceeded not only at a faster rate due to leaf rust, but also started sooner. In the experiment, the development stage at which leaf senescence started changed from DC 71 (Zadoks et al., 1974) (just after anthesis) in the absence of leaf rust to DC 63 (beginning of anthesis), being a period of 6 days $\left(112^{\circ} \mathrm{C}\right.$ d). For ear senescence, a change from DC 75 to $\mathrm{DC} 73$ was observed, being a period of 9 days $\left(130^{\circ} \mathrm{C} \mathrm{d}\right)$. The wheat genotypes did not differ significantly for these values.

The light intensity within the crop is reduced by light interception by both dead leaf and ear tissue and by leaf area covered with pustules. Leaf rust changes the distribution of dead leaf parts over crop height compared to a healthy crop, depending on the location of leaf rust. In the model, light interception and photosynthesis are calculated in a light competition submodel (Spitters, 1989; Rappoldt and Weaver, unpublished) in which six groups of competitors are distinguished: green and dead ear surface, green leaf area, leaf area covered by pustules, dead leaf area caused by leaf rust and dead 
leaf area caused by natural senescence. Instantaneous canopy phtotosynthesis is determined by performing a five-point Gaussian integration over the canopy height. Daily photosynthesis is calculated by a three-point Guassian integration over the daylength (Goudriaan, 1986; Spitters, 1989). Differences in photosynthesis of the competitors are explained by (a) the light interception capacity, which is a function of the area index $\left(\mathrm{m}^{2}\right.$ area $\mathrm{m}^{2}$ ground), the distribution over crop height and the light extinction coefficient; and (b) the photosynthetic capacity, characterized by the maximum photosynthesis at light saturation $\left(A_{\mathrm{m}}\right)$ and the light use efficiency $(\epsilon)$.

The distribution of the competitors is introduced as a function of crop height. Ears are assumed to form one layer just above the leaf mass. Natural leaf senescence is assumed to proceed from the bottom upwards. Dead leaf area caused by leaf rust is distributed negative exponentially with crop height from the botton upwards, as measured in the field:

$$
\begin{aligned}
& L D_{\mathrm{d}}=L D_{\mathrm{d}, \mathrm{m}} \cdot \exp \left(-\mathrm{b}\left(h-h_{\mathrm{l}}\right) /\left(h_{\mathrm{m}}-h_{\mathrm{l}}\right)\right) \\
& L D_{\mathrm{g}}=L D_{\mathrm{g}, \mathrm{m}}-L D_{\mathrm{d}}
\end{aligned}
$$

where $L D_{\mathrm{u}}$ and $L D_{\underline{g}}$ are the leaf area densities of dead and green leaf areas respectively ( $\mathrm{m}^{2}$ leaf $\mathrm{m}^{-2}$ ground $\mathrm{m}$ 'height); $L D_{\mathrm{d}, \mathrm{m}}$ and $L D_{\mathrm{g}, \mathrm{m}}$ are the maximum values of the leaf area densities and depend on total LAI and crop height; $h_{1}$ and $h_{\mathrm{m}}$ are, respectively, the minimum and maximum heights at which green leaves are present; $b$ is a parameter reflecting the steepness of the curve and was estimated from the experimental results as 4.4. Green leaf density, $L D_{p}$, is the difference between maximum leaf density, $L D_{\mathrm{g}, \mathrm{m}}$, and dead leaf density, $L D_{\mathrm{u}}$. Reduction of leaf area due to shrinking of senesced leaves has been taken into account and amounts to $40 \%$ (Veneklaas, unpublished).

\section{Results and discussion}

In the absence of leaf rust, the following model parameters differentiated the seven winter wheat genotypes: culm density, maximum size of leaves and ears and natural senescence rate for leaves and ears. In the presence of leaf rust, also leaf rust progress (described by a logistic function and characterized by initial pustule density, apparent infection rate and maximum pustule density), pustule size and relative senescence rate of leaves and ears caused by the disease explain differences between genotypes in the model. These parameter were quantified from the field experimental results and used as input for the model (Table 1).

In the absence of leaf rust. The simulated and measured grain yields at harvest in the absence of leaf rust are shown in Fig. la. Simulated grain yields agreed well with measured yields. For six genotypes, no significant difference was found between simulated and measured yield ( $P \leqq 0.05)$. Only in the case of 'Okapi', simulated yield was lower.

The sensitivity of grain yield to a parameter used in the simulation model has been calculated in the case of a $10 \%$ change in parameter value (Table 2). As an indication of the variation among genotypes to be expected, the genetic variation for the parameters is given, as derived from the field experiment (Table 1) or from Spitters and Kramer 
Table 1. Genotype specific parameters as derived from the experiment, which were used as input in the simulation model: the initial pustule density $N_{0}$ (10 days after inoculation), apparent infection rate $r$, maximum pustule density $N_{m}$, pustule size, death rate in the absence of leaf rust and relative death rate in the presence of leaf rust. Number of pustule days are given to characterize the cumulative disease intensity. Variation within and among genotypes is characterized by the environmental coefficient of variation $\left(C V_{\mathrm{c}}=\right.$ standard error/overall mean) and the genetic coefficient of variation ( $C V_{g}=$ genetic standard deviation/overall mean), respectively.

\begin{tabular}{|c|c|c|c|c|c|c|c|c|c|}
\hline \multirow[t]{4}{*}{ Wheat genotype } & \multicolumn{3}{|c|}{ Logistic growth curve } & \multirow{3}{*}{$\begin{array}{l}\text { Pustule } \\
\text { days }\end{array}$} & \multirow[t]{3}{*}{$\begin{array}{l}\text { Pustule } \\
\text { size }\end{array}$} & \multirow{2}{*}{\multicolumn{2}{|c|}{$\begin{array}{l}\text { Death rate, } \\
\text { control }\end{array}$}} & \multirow{2}{*}{\multicolumn{2}{|c|}{$\begin{array}{l}\text { Rel. death rate, } \\
\text { inoculated }\end{array}$}} \\
\hline & \multirow{2}{*}{$N_{0}$} & \multirow{2}{*}{$r$} & \multirow{2}{*}{$N_{\mathrm{m}}$} & & & & & & \\
\hline & & & & & & leaf & ear & leal & car \\
\hline & $\begin{array}{l}\mathrm{N} \mathrm{cm} 2 \\
\text { leaf } \\
\left(\times 10^{-4}\right)\end{array}$ & d 1 & $\begin{array}{l}\mathrm{Ncm} 2 \\
\text { leal }\end{array}$ & $\begin{array}{l}\mathrm{Nem} 2 \\
\text { leaf } \mathrm{d}\end{array}$ & $m m^{2}$ & \multicolumn{2}{|c|}{$\begin{array}{l}m^{2} \mathrm{~m}^{2} \\
\text { ground } \\
{ }^{\circ} \mathrm{C}^{\mathrm{d}} 1 \\
\left(\times 10^{3}\right)\end{array}$} & \multicolumn{2}{|c|}{$\begin{array}{l}N \mid \mathrm{cm}^{2} \\
{ }^{\circ} \mathrm{C} / \mathrm{d} \\
\left(\times 10^{4}\right)\end{array}$} \\
\hline 'Cappele Desprez' & 4.3 & 0.33 & 22.4 & 588 & 0.53 & 1.57 & 2.94 & 3.19 & 1.48 \\
\hline 'Okapi' & 8.0 & 0.29 & 22.6 & 494 & 0.92 & 1.56 & 3.89 & 3.86 & 4.00 \\
\hline 'Heine's II' & 6.0 & 0.30 & 28.5 & 527 & 0.75 & 2.05 & 3.50 & 5.21 & 3.62 \\
\hline \multicolumn{10}{|l|}{ 'Halle stamm } \\
\hline $6728-45$ & 4.8 & 0.21 & 1.0 & 20 & - & 1.80 & 2.82 & 24.25 & 31.70 \\
\hline 'Cerco’' & 2.0 & 0.43 & 133.3 & 3332 & 0.96 & 1.92 & 3.22 & 0.72 & 0.27 \\
\hline 'SVP-73035-45-1' & 16.5 & 0.25 & 23.7 & 385 & 0.74 & 2.00 & 2.84 & 5.69 & 1.30 \\
\hline 'SVP-73043-38-1' & 1.9 & 0.39 & 20.7 & 585 & 0.55 & 1.57 & 2.99 & 4.47 & 1.91 \\
\hline mean & 6.2 & 0.32 & 36.0 & 847 & 0.74 & 1.78 & 3.17 & 6.77 & 6.33 \\
\hline$C V_{\mathrm{e}}$ & $* 0.369$ & 0.047 & $*(0.365$ & $* 0.255$ & 0.108 & 0.024 & 0.048 & $* 0.218$ & ${ }^{*} 0.294$ \\
\hline$C V_{\mathrm{g}}$ & $* 0.55$ & 0.25 & $* 1.24$ & $* 1.39$ & 0.22 & 0.12 & 0.13 & $* 1.06$ & $* 1.28$ \\
\hline
\end{tabular}

* Standard deviations (SE, $\sigma_{y}$ ) for log-transformed data.

Table 2. Simulated percentage change in grain yield (in the absence of leaf rust) due to a $10^{\circ}$ change in the respective parameter value. As an indication of the expected variation among. genotypes, the genetic variation for the parameters is given as estimated from the field experiment or derived from Spitters and Kramer (1986), the latter marked by *.

\begin{tabular}{|c|c|c|c|c|c|}
\hline \multirow[t]{2}{*}{ Parameter } & \multirow[t]{2}{*}{ Unit } & \multirow[t]{2}{*}{$\begin{array}{l}\text { Relerence } \\
\text { value }\end{array}$} & \multicolumn{2}{|c|}{$\begin{array}{l}\text { Change in } \\
\text { parameter }\end{array}$} & \multirow[t]{2}{*}{${ }^{0} \mathrm{CV}_{\mathrm{g}}$} \\
\hline & & & $-10 \%$ & $+10 \%$ & \\
\hline Number of culms & $\mathrm{Nm}^{-2}$ & 332 & -5.52 & 5.20 & 13 \\
\hline Size 3 upper leaves & $\mathrm{cm}^{2}$ & 69 & -5.48 & 4.90 & 11 \\
\hline$\epsilon$ leaf & $\mathrm{kg}$ ha ${ }^{1} \mathrm{~h}{ }^{1} \mathrm{~J}-1 \mathrm{~m}^{2} \mathrm{~s}$ & 0.45 & -4.71 & 4.21 & $* 0$ \\
\hline$A_{\mathrm{m}}$ & $\mathrm{kg}$ ha ${ }^{\prime} \mathrm{h} \cdot 1$ & 40 & -3.89 & 3.46 & $* 5-10$ \\
\hline Death rate leaf & $\mathrm{m}^{2} \mathrm{~m}^{2}$ ground ${ }^{\circ} \mathrm{C}^{1} \mathrm{~d}{ }^{1}$ & 0.00178 & 3.63 & -3.07 & 12 \\
\hline Maintenance respiration & $\mathrm{kg} \mathrm{CH} \mathrm{CH}_{2} \mathrm{Og}{ }^{\prime} \mathrm{DM}$ & - & 2.67 & -2.56 & $* 20$ \\
\hline Maximum ear size & $\mathrm{cm}^{2}$ & 11.4 & -0.87 & 0.86 & 22 \\
\hline$\epsilon$ ear & $\mathrm{kg}$ ha ${ }^{1} \mathrm{~h}^{1} \mathrm{~J}{ }^{1} \mathrm{~m}^{2} \mathrm{~s}$ & 0.40 & -0.79 & 0.71 & - \\
\hline$A_{\mathrm{m}}$ & $\mathrm{kg}$ ha $1 \mathrm{~d} /$ & 30 & -0.78 & 0.70 & - \\
\hline Death rate ear & $\mathrm{m}^{2} \mathrm{~m}^{2}$ ground ${ }^{\circ} \mathrm{C}^{1} \mathrm{a}^{1}$ & 0.00317 & 0.43 & -0.36 & 13 \\
\hline
\end{tabular}


Table 3. Simulated yicld of control and inoculation treatment and yield reduction due to leaf rust for each wheat genotype if the same culm density of $332 \mathrm{culms} \mathrm{m}^{2}$ were applied to all genotypes.

\begin{tabular}{|c|c|c|c|c|}
\hline \multirow[t]{2}{*}{ Wheat genotype } & \multicolumn{2}{|c|}{ Grain yield (kg DM . ha ') } & \multicolumn{2}{|c|}{ Yield reduction } \\
\hline & control & diseased & kg DM. ha ${ }^{\prime}$ & $\%$ \\
\hline 'Cappelle Desprez' & 5917 & 4702 & 1215 & 20.5 \\
\hline 'Okapi' & 5215 & 4168 & 1047 & 20.1 \\
\hline 'Heine's II' & 5022 & 3743 & 1279 & 25.5 \\
\hline 'Halle stamm 6728-45' & 5085 & 5017 & 68 & 1.3 \\
\hline ‘Cerco' & 5037 & 3722 & 1315 & 26.1 \\
\hline 'SVP-73035-45-1' & 5347 & 4535 & 812 & 15.2 \\
\hline 'SVP-73043-38-1' & 5612 & 3776 & 1836 & 32.7 \\
\hline
\end{tabular}

(1986). Under the field experimental conditions, simulated grain yield was most sensitive to culm density and maximum leaf size, which together determine maximum leaf area index. Simulated grain yicld was also sensitive to light use efficiency $(\epsilon)$ and maximum leaf photosynthesis $\left(A_{\mathrm{m}}\right)$ at light saturation, which together characterize the leaf photosynthesis. Furthermore, simulated grain yield was sensitive to the leaf senescence rate, which determines the leaf area duration during grain filling.

When an average density of 332 culms $\mathrm{m}^{2}$ was introduced for all genotypes, variation in simulated grain yiclds decreased substantially due to the high sensitivity of yield to culm density (Table 3 versus Fig. la). The simulated variation in yield was now fully explained by measured differences in size of leaves and ears and rates of natural leaf and ear senescence. The maximum simulated yield difference was between 'Cappelle Desprez' and 'Heine's II' and amounted to $895 \mathrm{~kg} \mathrm{DM} \mathrm{ha}{ }^{-1}$, which was $15 \%$ of 'Cappelle Desprez's yield. This difference was explained for $56 \%$ by differences in leaf senescence rate and for $37 \%$ by differences in leaf size.

In the presence of leaf rust. Simulated and measured yields at harvest in the presence of leaf rust are shown in Fig. 1b. For six genotypes, simulated and measured yields did not differ significantly ( $P \leqq 0.05$ ). In the case of 'Halle stamm 6728-45', simulation overestimated observed yields and the deviation could not be explained. Measured yield of 'Halle stamm 6728-45' was low due to the low number of 28.6 kernels per ear, while 37.2 kernels per ear were measured in the control treatment. Only $20 \%$ of this measured reduction in kernels per ear was explained by the difference in culm density between control and inoculated treatment, when the relationship found by Darwinkel (1978) was applied.

To compare yield reduction between genotypes, yield has been simulated at an average culm density of 332 culms $\mathrm{m}^{-2}$ (Table 3 ). Simulated yield reduction caused by leaf rust varied between 68 and $1836 \mathrm{~kg} \mathrm{DM} \mathrm{ha}^{-1}$, being 1 to $33 \%$ of the yield in the absence of leaf rust.

To illustrate the importance of the individual components of yield reduction, these were simulated for 'Cappelle Desprez', by omitting the respective component during 


\section{CONTROL}

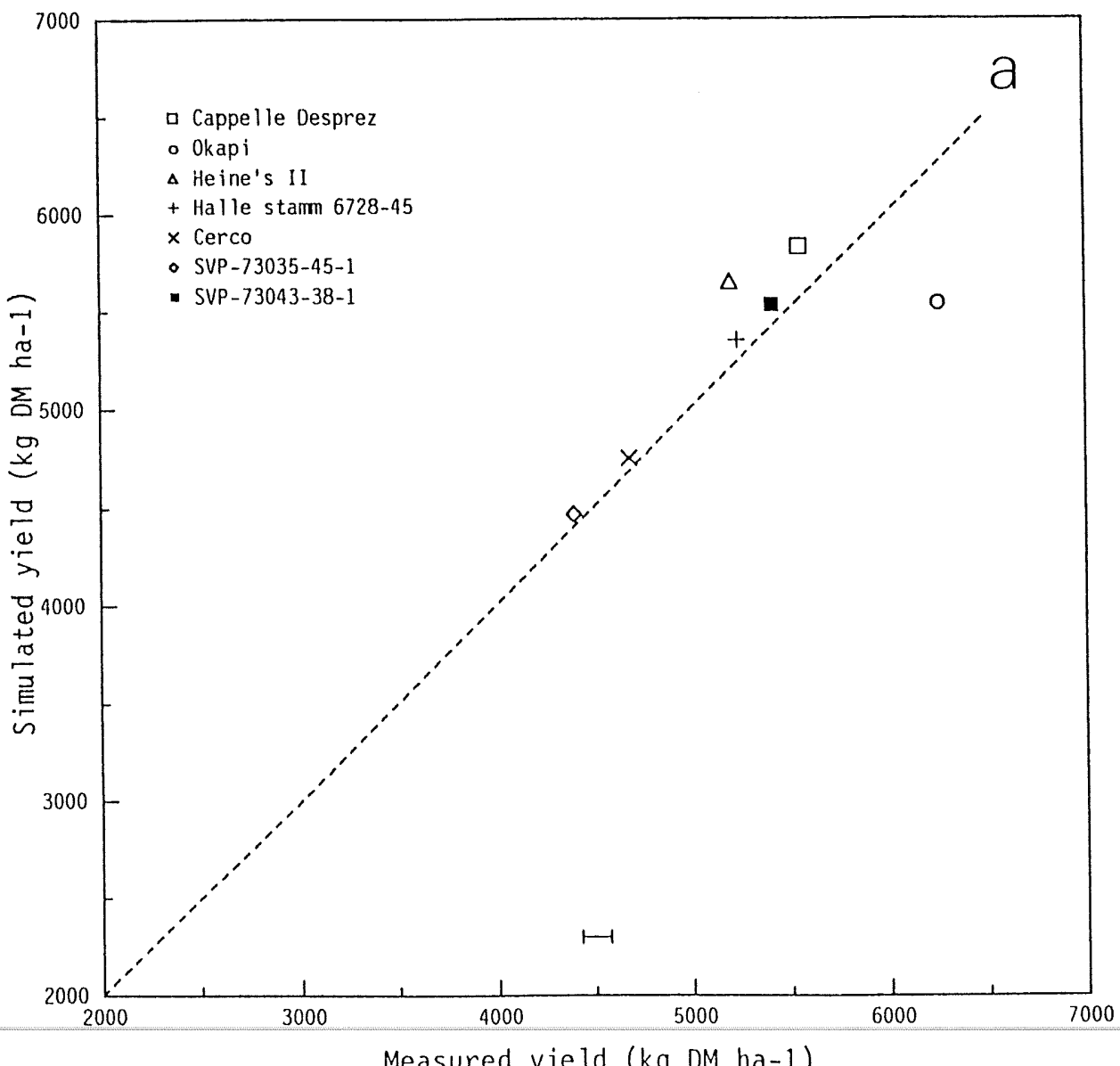

Fig. 1. Simulated and measured grain yield ( $\mathrm{kg} \mathrm{DM} \mathrm{ha}^{-1}$ ) of (a) control and (b) inoculation treatments. Depicted lines have a $45^{\circ}$ slope. Bars represent standard errors (SE) of the data points.

a simulation run (Table 4). Decrease in leaf surface due to accelerated leaf senescence was the major component and accounted for $65.5 \%$ of total yield reduction, due to a lower gross leaf photosynthesis. Light interception by dead leaf area at the top of the canopy also resulted in a lower gross leaf phtotsynthesis, due to shading of the green leaf area, and caused $17.9 \%$ of the total yield reduction. Altogether, accelerated leaf senescence due to leaf rust resulted in $83.4 \%$ of total yield reduction, $45 \%$ of which was due to a premature start and $55 \%$ to a faster rate of leaf senescence.

Acceleration of ear senescence (yellowing) affected yield reduction less than leaf senescence, because ear photosynthesis was only about $10 \%$ of the total gross photosynthesis (from 10 April onwards). It resulted in $8 \%$ of total yield reduction, $65 \%$ of which was due to a premature start and $35 \%$ to a faster rate of ear senescence.

Uptake of plant assimilates by the fungus for spore production accounted for $8.7 \%$ 


\section{DISEASED}

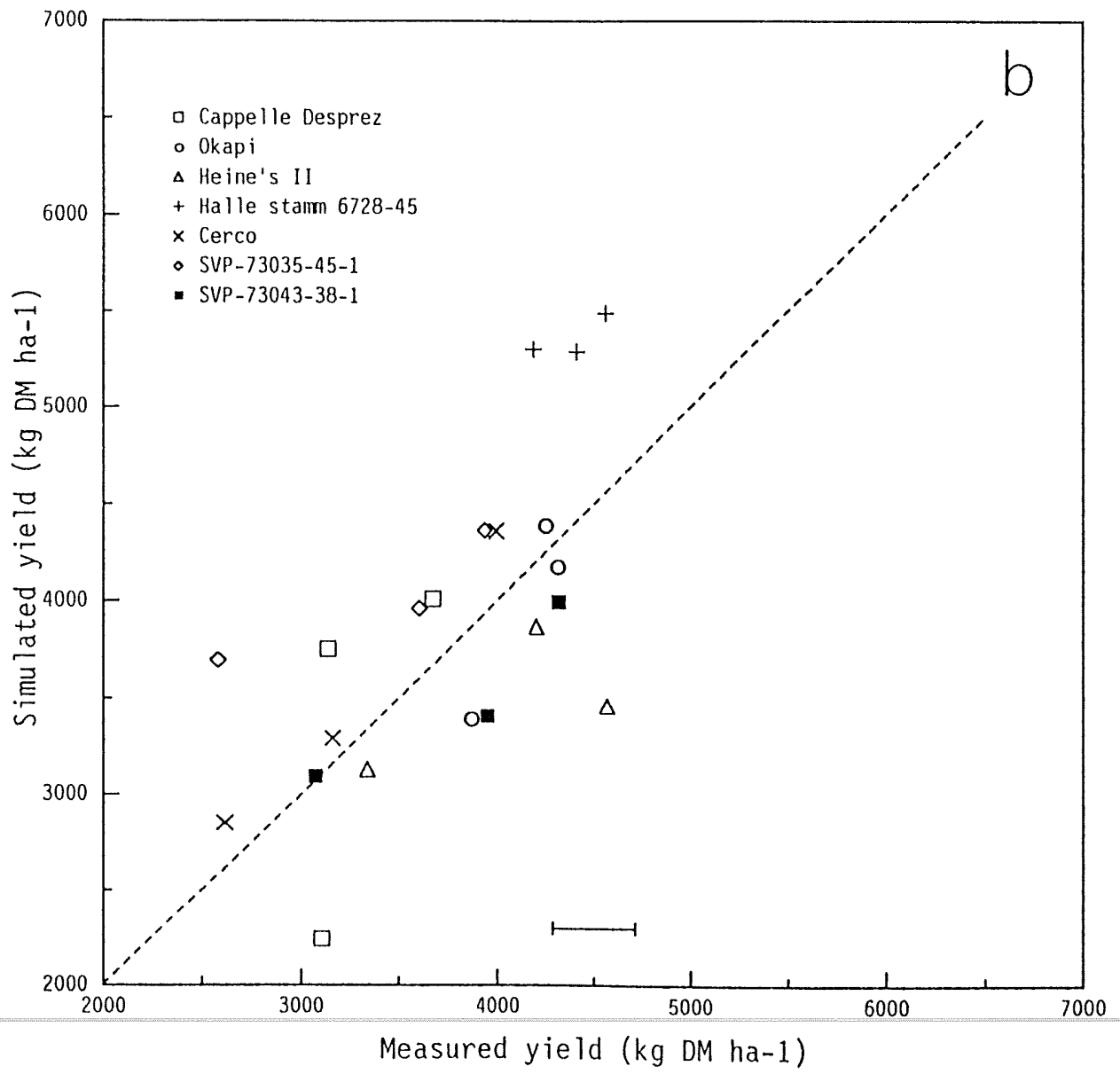

Table 4. Simulated effect of individual components on yield reduction (in $\%$ of total yield reduction) for 'Cappelle Desprez'. Total simulated yield reduction was $1215 \mathrm{~kg} \mathrm{DM} \mathrm{ha}^{-1}$, or $20.5 \%$ of yield in the absence of leaf rust of $5917 \mathrm{~kg} \mathrm{DM} \mathrm{ha}^{-1}$.

\section{Component of yield reduction}

Premature and accelerated leaf senescence

- decrease in leaf area index

- light interception by dead leaf area

Carbohydrate uptake for sporulation

Premature and accelerated ear senescence

- decrease in ear area index

- light interception by dead ears
$\%$ of total yield reduction

83.4

8.7

8.0

Leaf coverage by pustules before leaf death

0.2 
of total yield reduction. Simulated spore production was $140 \mathrm{~kg} \mathrm{ha}^{-1}$ spore dry mass, which required $230 \mathrm{~kg} \mathrm{CH}_{2} \mathrm{O} \mathrm{ha}{ }^{-1}$, resulting in a reduction of $105 \mathrm{~kg} \mathrm{ha}^{-1}$ grain dry matter. As quantitative data on mycelium biomass are not available, the effects of mycelium growth and maintenance are not taken into account. The sensitivity of grain yield to total assimilate uptake was calculated in a separate simulation run, assuming a spore/total fungus biomass ratio of 0.5 . Total carbohydrate uptake by the fungus was then $570 \mathrm{~kg} \mathrm{ha}^{-1}$ ( $81 \%$ for growth and $19 \%$ for maintenance), resulting in a reduction of $250 \mathrm{~kg} \mathrm{ha}^{-1}$ grain dry matter. Assimilate uptake by the fungus increased then from $8.7 \%$ to $18.3 \%$ of total yield reduction.

Coverage of green leaf area by pustules before leaf senescence was not an important component of yield reduction. At the start of leaf senescence, the pustule density was 3 pustules per $\mathrm{cm}^{2}$ leaf, which covers only $1.6 \%$ of the total leaf area.

The sensitivity of grain yield to parameters reflecting leaf rust interaction has been calculated in the case of a $10 \%$ change in parameter value (Table 5). Note that two parameters, the assimilate requirement for spores and the vertical distribution coefficient of leaf rust pustules in the canopy were assumed to be genotype non-specific. Simulated grain yield was most sensitive to the apparent infection rate of the disease which was of major importance in determining the number of pustule days and was the main cause of the accelerated leaf senescence. Simulated grain yield was less sensitive to the rate of leaf senescence caused by the disease. Simulated grain yield was not very sensitive to either the assimilate requirement for spores, pustule size or to the vertical distribution coefficient of leaf rust pustules in the canopy. However, when a uniform rather than an exponential distribution of leaf rust pustules over crop height was assumed, simulated total yield reduction of 'Cappelle Desprez' increased from $20.7 \%$ to $26.3 \%$

Table 5. Simulated percentage change in grain yicld (in the presence of leaf rust) due to a $10 \%$ change in the respective parameter value. The variation among the genotypes in the field experiment is characterized by the genctic cocfficient of variation $\left(\% \mathrm{CV}_{4}\right)$. The distribution coefficient characterizes the exponential leaf rust distribution over canopy height.

\begin{tabular}{|c|c|c|c|c|c|}
\hline Parameter & Unit & $\begin{array}{l}\text { Reference } \\
\text { value }\end{array}$ & $-10 \%$ & $+10 \%$ & ${ }_{0}{ }_{0} C V_{\mathrm{g}}$ \\
\hline \multicolumn{6}{|l|}{ Apparent infection rate } \\
\hline leaf rust & $\mathrm{d}^{\prime}$ & 0.32 & 13.60 & -9.49 & 25 \\
\hline Relative death rate leaf & $\mathrm{N}^{1} \mathrm{~cm}^{2}{ }^{\circ} \mathrm{C}^{1} \mathrm{~d}^{\prime}$ & 0.000677 & 1.87 & -1.62 & *106 \\
\hline Initial density leaf rust & $\mathrm{N} \mathrm{cm}^{2}$ leaf & 0.000620 & 1.17 & -1.05 & *55 \\
\hline $\begin{array}{l}\text { Maximum density leaf } \\
\text { rust }\end{array}$ & $\mathrm{N} \mathrm{cm}{ }^{2}$ leaf & 36.0 & 1.17 & -0.94 & $* 124$ \\
\hline Relative death rate ear & $\mathrm{N}^{-1} \mathrm{~cm}^{2}{ }^{\circ} \mathrm{C}^{1} \mathrm{~d}^{1}$ & 0.000633 & 0.26 & -0.23 & $* 130$ \\
\hline $\begin{array}{l}\text { spores } \\
\text { Distribution coefficient }\end{array}$ & 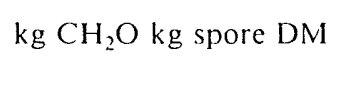 & 1.67 & 0.18 & -0.18 & - \\
\hline leaf rust & - & 4.4 & -0.11 & 0.08 & - \\
\hline Pustule size & $\mathrm{mm}^{2}$ & 0.74 & 0.01 & -0.01 & 22 \\
\hline
\end{tabular}

* Standard deviations (SE, $\sigma_{\mathrm{g}}$ ) for log-transformed data. 
The breeding perspectives of different components can be assessed by their simulated effect on crop yield and the genetic variation found for the component. The breeding strategy is based on maximalizing the correlated response for yield after selection for the component. The correlated response for grain yield $\left(C R_{\mathrm{y}}\right)$ after selection for a trait $\mathrm{x}$ is the multiplication of the direct response for trait $\mathrm{x}\left(R_{\mathrm{x}}\right)$ and the regression of yield on trait $x\left(b_{y, x}\right)$ (Falconer, 1960):

$$
C R_{\mathrm{y}}=R_{\mathrm{x}} \cdot b_{\mathrm{y} \cdot \mathrm{x}}=i_{\mathrm{x}} \cdot h_{\mathrm{x}} \cdot C V_{\mathrm{g}, \mathrm{x}} \cdot b_{\mathrm{y}, \mathrm{x}}
$$

where $i$ is the selection intensity and $h$ the square root of the heritability $\left(h^{2}=\right.$ $\left.C V_{g}^{2} /\left(C V_{g}^{2}+C V_{c}^{2}\right)\right)$. The regression coefficient can be calculated using the simulation model and indicates the sensivity of yield to trait $x$. For instance, the regression of yield on apparent infection rate of the epidemic can be derived from Table 5 to be $(13.60+9.49) / 20=1.15$. Estimates of the genetic and environmental coefficients of variation are given for various traits in Table 1 and by Spitters et al. (1990). Multiplication of the regression coefficient $b_{y . x}$ by the genetic coefficient of variation $C V_{g}$, observed in the field experiment, gives a rough indication of the increase in grain yield which may be expected in the long term after selection for the trait. Expected increase in grain yield is large as far as the apparent infection rate of leaf rust and the relative rate of leaf senescence depending on disease intensity are concerned, given the observed variation in these characters among the genotypes in the experiment. The apparent infection rate can be considered to be a component of partial resistance (VanderPlank, 1963; Parlevliet, 1979). Relative leaf senescence rate, dependent upon disease intensity, might be a component of crop tolerance, because at equal amounts of disease, a difference in leaf senescence rate results in differences in yield.

\section{Acknowledgements}

We are grateful to H.G.M.G. van Nassau, K. van Spanje and J. Schepers (Foundation for Agricultural Plant Breeding (SVP), Wageningen) for performing the field measurements.

\section{Samenvatting}

Simulatie van opbrengstderving door bruine roest in wintertarwe, toegepast op de analyse van genetische variatie in partiële resistentie

Verschillen tussen zeven wintertarwegenotypen in opbrengstderving door bruine roest, zoals waargenomen in een veldexperiment, werden geanalyseerd met een simulatiemodel. In dit model werd het effect van de ziekte op gewasgroei en opbrengst beschreven op basis van lichtinterceptie, fotosynthese, ademhaling en assimilatenverdeling. Het model gaf een goede beschrijving van de waargenomen opbrengstverschillen tussen de genotypen, zowel bij aanwezigheid als bij afwezigheid van bruine roest. Van de totale opbrengstreductie werd, volgens modelberekeningen, $66 \%$ veroorzaakt door versnelde afname van groen bladoppervlak en $18 \%$ door het wegvangen van licht door dood bladweefsel boven in het gewas. De genetische variatie in opbrengstreductie werd zodoende vooral verklaard uit de waargenomen verschillen in bladveroudering tussen de

Neth. J. Pl. Path. 96 (1990) 
genotypen. De fotosynthese per eenheid resterend groen bladoppervlak werd niet beïnvloed door bruine roest. Respectieven voor selectie op afzonderlijke schadecomponenten werden geëvalueerd op basis van hun gesimuleerde effect op korrelopbrengst, in combinatie met hun genetische en toevalsvariatie.

\section{References}

Calow, P., 1977. Conversion efficiencies in heterotrophic organisms. Biological Review 52: 385-409.

Clarke, D.D., 1986. Tolerance of parasites and disease in plants and its significance in host-parasite interactions. Advances in Plant Pathology 5: 161-197.

Darwinkel, A. 1978. Patterns of tillering and grain production of winter wheat at a wide range of plant densities. Netherlands Journal of Agricultural Science 26: 383-398.

Falconer, D.S., 1960. Introduction to quantitative genetics. Oliver \& Boyd, Edinburgh, 365 pp.

Goudriaan, J., 1986. A simple and fast numerical method for the computation of daily totals of crop photosynthesis. Agricultural and Forest Meteorology 38: 249-254.

James, W.C., 1974. Assessment of plant diseases and losses. Annual Review of Phytopathology 12: $27-48$.

Kuhn, R.C., Olım, H.W. \& Shaner, G.E., 1978. Slow leaf-rusting resistance in wheat against twentytwo isolates of Puccinia recondita. Phytopathology 68: 651-656.

Mehta, Y.R. \& Zadoks, J.C., 1970. Uredospore production and sporulation period of Puccinia recondita f.sp. triticina on primary leaves of wheal. Netherlands Journal of Plant Pathology 76: $267-276$.

Oijen, M. van, 1989. On the use of mathematical models from human epidemiology in breeding for resistance to polycyclic fungal leaf diseases of crops. In: Parental line breeding and selection in potato breeding. Procecdings EAPR Breeding Section and EUCARPA Potato Section Conference. Pudoc, Wageningen, the Netherlands. p. 26-37.

Parlevliet, J.E., 1979. Components of resistance that reduce the rate of epidemic development. Annual Review of Phytopathology 17: 203-222.

Penning de Vries, F.W.T., Laar, H.H. van \& Chardon, M.C.M., 1983. Bioenergetics of growth of seeds, fruits and storage organs. In: Potential productivity of field crops under different environments. IRRI, Los Banos, Philippines, p. 37-59.

Shaner, G. \& Hess, F.D., 1978. Equations for integrating components of slow leaf-rusting resistance in wheat. Phytopathology 68: 1464-1469.

Shaw, M., 1964. The physiology of rust uredospores. Phytopathologisch Zeitschrift 50: 159-180.

Spitters, C.J.T., 1989. Weeds: population dynamics, germination and competition. In: Rabbinge, R., Ward, S.A. \& Laar, H.H. van (Eds), Simulation and systems management in crop protection. Simulation Monographs, Pudoc, Wageningen. 420 pp.

Spitters, C.J.T. \& Kramer, Th., 1986. Differences between spring wheat cultivars in early growth. Euphytica 35: 273-292.

Spitters, C.J.T., Keulen, H. van \& Kraalingen, D.W.G. van, 1989. A simple and universal crop growth simulator: SUCROS87. In: Rabbinge, R., Ward, S.A. \& Laar, H.H. van (Eds), Simulation and systems management in crop protection. Simulation Monographs, Pudoc, Wageningen. $420 \mathrm{pp}$,

Spitters, C.J.T., Roermund, H.J.W. van, Nassau, H.G.M.G. van, Schepers, J., Mesdag, J., 1990. Genetic variation in partial resistance to leaf rust in winter wheat: disease progress, foliage senescence and yield reduction. Netherlands Journal of Plant Pathology 96: 3-15.

VanderPlank, J.E., 1963. Plant Diseases: Epidemics and Control. New York \& London. Academic. $206 \mathrm{pp}$.

Zadoks, J.C., Chang, T.T., Konzak, C.F., 1974. A decimal code for the growth stages of cereals. Eucarpia Bulletin 7. $11 \mathrm{pp}$. 